\title{
Altered Growth, Differentiation, and Responsiveness to Epidermal Growth Factor of Human Embryonic Mesenchymal Cells of Palate by Persistent Rubella Virus Infection
}

Toshiyuki Yoneda, Masahiro Urade, Masayoshi Sakuda, and Tadashi Miyazaki

First and Second Department of Oral and Maxillofacial Surgery, Faculty of Dentistry, Osaka University, Suita, Osaka 565 Japan

\begin{abstract}
We previously demonstrated that human embryonic mesenchymal cells derived from the palate (HEMP cells) retain alkaline phosphatase (ALP) content and capacity for collagen synthesis after long-term culture, and their growth is markedly stimulated by epidermal growth factor (EGF). There was a dramatic decrease in ALP content and capacity to synthesize collagen in HEMP cells (HEMP-RV cells) persistently infected with rubella virus (RV). EGF increased ALP activity and decreased collagen synthesis in HEMP cells, whereas EGF showed no effect on these activities in HEMP-RV cells. Growth of HEMP-RV cells was slightly reduced compared with that of HEMP cells. EGF stimulated growth of HEMP cells and to a lesser extent of HEMP-RV cells. Binding of ${ }^{125}$ I-EGF to cell-surface receptors in HEMP-RV cells was, to our surprise, twice as much as that in HEMP cells. However, internalization of bound ${ }^{125} \mathrm{I}$-EGF in HEMP-RV cells was profoundly diminished. Thus, persistent $R V$ infection causes not only changes in HEMP cell growth and differentiation but a decrease in or loss of HEMP cell responsiveness to EGF. The effects of persistent $R V$ infection on palatal cell differentiation as well as growth may be responsible for the pathogenesis of congenital rubella. Furthermore, since HEMP cells appear to be closely related to osteoblasts, these results suggest a mechanism for RV-induced osseous abnormalities manifested in congenital rubella patients.
\end{abstract}

\section{Introduction}

Since the first report described by Gregg in 1941 (1), much attention has been paid to the teratogenic and pathogenic effects of rubella virus (RV). ${ }^{1}$ Clinical studies on wide-spread and virulent rubella epidemics that occurred throughout the United States in $1964(2,3)$ have indicated that RV is one of the most dangerous viruses that affects developing fetuses to cause congenital malformations. The virulence of RV was emphasized by

Requests for reprints should be addressed to Dr. Yoneda, Second Department of Oral and Maxillofacial Surgery, Faculty of Dentistry, Osaka University, 1-8 Yamadaoka, Suita, Osaka 565, Japan.

Received for publication 27 November 1984 and in revised form 13 December 1985.

1. Abbreviations used in this paper: ALP, alkaline phosphatase; DME, Dulbecco's modified Eagle's medium; EGF, epidermal growth factor; FBS, fetal bovine serum; HEMP cell, human embryonic mesenchymal cells from palate; HEMP-RV cells, HEMP cells persistently infected with rubella virus; pfu, plaque-forming unit; $R V$, rubella virus.

J. Clin. Invest.

(C) The American Society for Clinical Investigation, Inc.

$0021-9738 / 86 / 05 / 1613 / 09 \quad \$ 1.00$

Volume 77, May 1986, 1613-1621 the experiments of Cotlier et al., who found that maternal infection with $R V$ results in an induction of congenital rubella diseases in rat embryos and newborns similar to those seen in human (4). Severe clinical manifestations such as heart disease, eye defects, and deafness may be first noted in infancy (5) and it is likely that these manifestations resulted from the effects of RV on the developing fetus during a critical period of organogenesis. However, little is known of the mechanisms by which $\mathrm{RV}$ induces these malformations, partly because a suitable in vitro experimental system has not been developed.

We have recently isolated human embryonic mesenchymal cells from palate cells (HEMP cells) (6). We have found that the cells possess specific receptors for epidermal growth factor (EGF) and their growth is markedly stimulated by EGF $(6,7)$. Furthermore, recently we have found that HEMP cells show increasing alkaline phosphatase activity (ALP) after confluency and synthesize type 1 collagen $(8),{ }^{2}$ similar to cells with the mature osteoblast phenotype. These results suggest that HEMP cells provide a useful model for biochemical studies on the effects of persistent RV infection on cellular growth and differentiation.

In the present experiments, we first attempted to establish HEMP cells persistently infected with RV (HEMP-RV cells) in culture. We then studied their biochemical properties in comparison with those of uninfected HEMP cells in an attempt to gain insight into the mechanisms responsible for $\mathrm{RV}$-induced diseases that occur in human embryos and newborns.

\section{Methods}

Culture of HEMP and HEMP-RV cells. HEMP and HEMP-RV cells were grown in Dulbecco's modified Eagle's medium (DME; Nissui Pharmaceutical Co., Tokyo, Japan) supplemented with 5\% (vol/vol) heatinactivated fetal bovine serum (FBS; Gibco, Grand Island, NY) and 1\% (vol/vol) penicillin-streptomycin solution (Flow Laboratories, North Ryde, Australia) in a humidified atmosphere containing $95 \%$ air and $5 \%$ $\mathrm{CO}_{2}$ at $37^{\circ} \mathrm{C}$. The culture medium was changed every $2 \mathrm{~d}$. When the cells became confluent (10-14 d after inoculation) they were harvested with $0.05 \%$ trypsin- $0.02 \%$ EDTA solution, and subcultured at a split ratio $1: 3$ and were grown as described above (9). In the following experiments, HEMP cells at the 10th to 20th passage were used.

Virus and virus assay. RV-strain M-33 was plaque purified and propagated on BHK 21/WI-2 cell cultures in DME supplemented with $5 \%$ calf serum. The culture medium was harvested at $\sim 5 \mathrm{~d}$ postinfection, centrifuged, and stored at $-70^{\circ} \mathrm{C}$ as the virus stocks until used. The infectious viruses were assayed by plaque forming ability on BHK 21/ WI-2 cell monolayers (10). The cells were plated onto plastic dishes (Falcon Plastics, Div. of Becton-Dickinson \& Co., Los Angeles, CA) at a density of $10^{6} / 60-\mathrm{mm}$ dish and incubated in a humidified atmosphere containing $95 \%$ air and $5 \% \mathrm{CO}_{2}$ at $37^{\circ} \mathrm{C}$. Confluent cell monolayers formed after $2 \mathrm{~d}$ of incubation were infected with virus samples in serial 10-fold dilutions. After adsorption for $2 \mathrm{~h}$ at $37^{\circ} \mathrm{C}$, the cultures were

2. Yoneda, T., N. Nishikawa, M. Ohmae, and M. Sakuda, manuscript in preparation. 

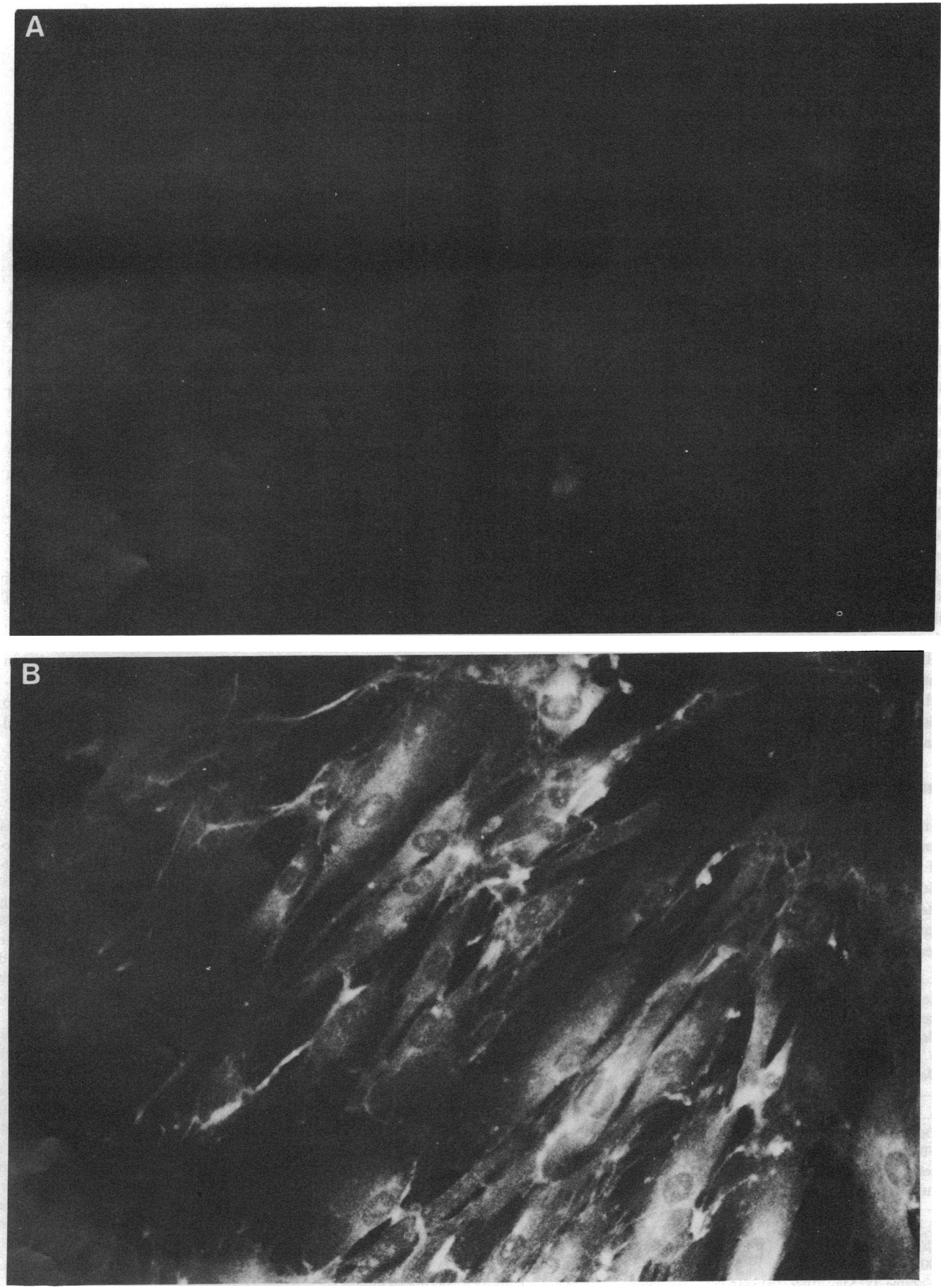
washed once with DME, overlaid with the same fresh medium containing 0.7\% Agar Noble (Difco Laboratories, Detroit, MI) and incubated for 6 d at $37^{\circ} \mathrm{C}$. Plaques formed were stained with $0.3 \%$ neutral red solution in Dulbecco's phosphate-buffered saline (PBS) (11) and counted.

Detection of viral antigens by indirect immunofluorescence antibody technique. RV-infected and uninfected cells grown on coverslips at $37^{\circ} \mathrm{C}$ were washed three times with PBS and fixed in acetone for $15 \mathrm{~min}$ at $4^{\circ} \mathrm{C}$. The coverslips were air-dried and then mounted with anti-RV rabbit antiserum (Flow Laboratories, Rockville, MD) diluted 1:10 in PBS. After incubation for $60 \mathrm{~min}$ at $37^{\circ} \mathrm{C}$, the coverslips were washed extensively with PBS and incubated with fluorescein isothiocyanate-conjugated antirabbit IgG swine antiserum (Dakopatts A/S, Denmark) for 60 min at $37^{\circ} \mathrm{C}$. The coverslips were washed three times with PBS and subsequently mounted in $90 \%$ (vol/vol) glycerol-carbonate buffer (pH 9.4) and examined on fluorescence microscope (type ELS, Nikon, Tokyo, Japan) (12).

Cell division. HEMP or HEMP-RV cells were plated at a density of $2 \times 10^{4} / 17-\mathrm{mm}$ dish in DME supplemented with 5\% FBS. On the next day, the medium was replaced by serum-free DME supplemented with or without EGF $(10 \mathrm{ng} / \mathrm{ml})$ and the cells were grown for $4 \mathrm{~d}$. The medium was changed every $2 \mathrm{~d}$. The cells were harvested with $0.05 \%$ trypsin$0.02 \%$ EDTA solution and stained with $0.05 \%$ trypan blue. Counting of the cells that excluded the dye was performed on a hemocytometer.

DNA synthesis. HEMP or HEMP-RV cells were plated at a density of $2 \times 10^{4} / 17-\mathrm{mm}$ dish and cultured in DME supplemented with $5 \%$ FBS until they became subconfluent (5-7 d). The cells were then incubated in serum-free DME supplemented with or without EGF (10 ng/ $\mathrm{ml}$ ) for $48 \mathrm{~h}$. For the last 4-6 h of incubation, the cells were labelled with $1 \mu \mathrm{Ci} / \mathrm{ml}\left[{ }^{3} \mathrm{H}\right]$ thymidine $(90-110 \mathrm{Ci} / \mathrm{mmol}$, New England Nuclear, Boston, MA) in fresh serum-free DME. At the end of the incubation, the cells were rinsed twice with ice-cold PBS and treated with 5\% trichloroacetic acid (TCA) for $30 \mathrm{~min}$ at $4^{\circ} \mathrm{C}$, washed twice with ice-cold TCA and once with ice-cold methanol and were solubilized with $1 \mathrm{M}$ $\mathrm{NaOH}$. Radioactivity was counted in a liquid scintillation spectrometer (LKB Instruments, Inc., Gaithersburg, MD) (9).

Alkaline phosphatase $(A L P)$. After the cells $\left(2 \times 10^{5} / 17 \mathrm{~mm}\right)$ were cultured and incubated for periods as indicated in DME supplemented with $5 \%$ FBS and containing $5 \mathrm{mM}$ glycerophosphate or in serum-free DME containing $5 \mathrm{mM}$ glycerophosphate in the presence or absence of EGF (Collaborative Research, Waltham, MA), they were scraped with a rubber policeman in $0.5 \mathrm{ml}$ distilled water and sonicated. ALP activity was assayed according to the method of Majeska and Rodan (13) which was modified from Lowry (14). The assay mixtures consisted of $0.1 \mathrm{M}$ carbonate buffer ( $\mathrm{pH} 10.0$ ), $2 \mathrm{mM} \mathrm{MgCl}_{2}, 2 \mathrm{mM}$ disodium $P$-nitrophenylphosphate (Wako Pure Chemical Industries, Co., Osaka, Japan), and $1-1.5 \mu \mathrm{g}$ protein $(25 \mu \mathrm{l})$ in a total volume of $0.2 \mathrm{ml}$. The incubations were carried out for $20 \mathrm{~min}$ and terminated by the addition of $0.8 \mathrm{ml}$ of $0.25 \mathrm{M} \mathrm{NaOH}$ and absorbance was read at $410 \mathrm{~nm}$.

Mineral deposition. HEMP or HEMP-RV cells $\left(2 \times 10^{5} / 17-\mathrm{mm}\right.$ dish) were cultured in DME supplemented with $5 \%$ FBS for $10 \mathrm{~d}$. Confluent phosphate for 15-20 d and then were stained by the von Kossa silver nitrate method (15).

Collagen synthesis. HEMP or HEMP-RV cells $\left(2 \times 10^{5} / 17-\mathrm{mm}\right.$ dish $)$ were cultured in DME supplemented with 5\% FBS for $10 \mathrm{~d}$. Confluent HEMP or HEMP-RV cells were cultured in serum-free DME supplemented with $50 \mu \mathrm{g} / \mathrm{ml}$ ascorbic acid (Wako Pure Chemical Industries, in the presence or absence of EGF $(10 \mathrm{ng} / \mathrm{ml})$ for $48 \mathrm{~h}$ and were incubated for $2 \mathrm{~h}$ in the same fresh medium containing $5 \mu \mathrm{Ci} / \mathrm{ml} \mathrm{L}\left[{ }^{3} \mathrm{H}\right]$ proline $(100$ $\mu \mathrm{Ci} / \mathrm{mmol}$, New England Nuclear) and $64 \mu \mathrm{g} / \mathrm{ml} \beta$-aminopropionitrile fumarate (Tokyo Chemical Industries, Co., Tokyo). The cell layer was scraped with rubber policeman, sonicated, dialyzed against $0.15 \mathrm{M} \mathrm{NaCl}$, $0.05 \mathrm{M}$ Tris- $\mathrm{HCl}$ (pH 7.4) containing 1:7 mM phenylmethylsulfonyl fluoride (Calbiochem-Behring Corp., La Jolla, CA) and $1 \mathrm{mM}$ L-proline
(16) and digested with chromatographically purified bacterial collagenase (type III, Worthington Diagnosis Systems Inc., Freehold, NJ) for $3 \mathrm{~h}$ at $37^{\circ} \mathrm{C}$ (9). We confirmed that the collagenase used had no protease activity according to the method described (17). The reaction was stopped by adding 10\% TCA and 10\% tannic acid (Wako Pure Chemical Industries, Co.) and the reaction mixture was kept at $4^{\circ} \mathrm{C}$ for $30 \mathrm{~min}$, centrifuged at $1,500 \mathrm{~g}$ for $15 \mathrm{~min}$ and the supernatants were transferred to counting vials. The precipitates were resuspended in $5 \%$ TCA and $0.25 \%$ tannic acid, recentrifuged, and the supernatants were combined with the first supernatants and their radioactivity was measured (collagenous protein). The precipitates were solubilized with $0.5 \mathrm{M} \mathrm{NaOH}$ and their radioactivity was counted (noncollagenous protein). Percent collagen synthesized was calculated by the formula described (18).

$E G F$ receptor assay. Specific ${ }^{125}$ I-EGF binding to HEMP or HEMPRV cells was measured as described previously (6). After HEMP or HEMP-RV cells $\left(2 \times 10^{5} / 17-\mathrm{mm}\right.$ dish) were cultured for $10 \mathrm{~d}$ in DME supplemented with $5 \%$ FBS, the culture media were aspirated and the cells were gently washed twice with $1 \mathrm{ml}$ of binding buffer (DME containing $1 \mathrm{mg} / \mathrm{ml}$ bovine serum albumin, $50 \mathrm{U} / \mathrm{ml}$ penicillin, $50 \mu \mathrm{g} / \mathrm{ml}$

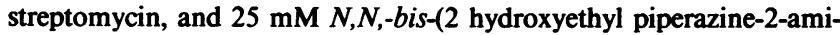
noethanesulfonic acid at $\mathrm{pH} 7.4$ ) at $4^{\circ} \mathrm{C}$ and subsequently $1 \mathrm{ml}$ of binding buffer was added to each dish. $0.05-0.5 \mu \mathrm{Ci}$ of ${ }^{125}$ I-labeled mouse EGF $(150-200 \mu \mathrm{Ci} / \mathrm{g}$, New England Nuclear) in $10 \mu \mathrm{l}$ of PBS was then added and the cells were incubated for $1 \mathrm{~h}$ at room temperature. At the end of incubation, the cells were washed five times with $1 \mathrm{ml}$ of binding buffer at $4^{\circ} \mathrm{C}$ to remove unbound ${ }^{125}$ I-EGF and solubilized in $1 \mathrm{ml}$ of lysing buffer $(0.1 \mathrm{M}$ Tris- $\mathrm{HCl}$, pH 7.4 containing $0.5 \%$ sodium dodecyl sulfate and $1 \mathrm{mM}$ EDTA) and rinsed with $1 \mathrm{ml}$ of lysing buffer. The combined contents were transferred to counting vials and radioactivity was counted. Nonspecific binding was determined in the presence of $2 \mu \mathrm{g}$ of unlabeled mouse EGF and was always $<5 \%$ of the total binding. Specific binding was obtained by subtracting nonspecific binding from total binding.

125 I-EGF internalization. The extent of EGF internalization was determined by the method of Haigler et al. (19). Cultures were incubated with $0.2 \mathrm{Ci}$ of ${ }^{125} \mathrm{I}$-EGF for short periods of time at $37^{\circ} \mathrm{C}$ to allow membrane-bound ${ }^{125} \mathrm{I}$-EGF to internalize. After removal of the unbound EGF by rinsing with $1 \mathrm{ml}$ ice-cold binding buffer, the cultures were extracted at $4^{\circ} \mathrm{C}$ for $4 \mathrm{~min}$ with $0.2 \mathrm{M}$ acetic acid and $0.5 \mathrm{M} \mathrm{NaCl}$ (pH 2.5). Each plate was rinsed once with the same buffer. The cells were then solubilized by $1 \mathrm{ml}$ lysing buffer. Radioactivity in the acid and the lysing buffer was counted separately and represents the amount of externally bound and internalized ${ }^{125}$ I-EGF, respectively.

Protein. Protein was measured by the method of Lowry et al. (20) using bovine serum albumin (Sigma Chemical Co., St. Louis, MO) as a standard.

Statistics. Data were analyzed by Student's t test for unpaired samples.

\section{Results}

Establishment of HEMP-RV cells. When HEMP cells were infected with RV at a multiplicity of infection of 0.1 , they supported $R V$ replication and produced infectious viruses at a titer of $10^{4}$ plaque-forming units $(\mathrm{pfu}) / \mathrm{ml}$ at $4 \mathrm{~d}$ postinfection with a slight cytopathic effect. After 1 mo cultivation, infected HEMP cells were maintained in stable culture and grew with a spontaneous release of infectious virus particles into the culture medium. Indirect immunofluorescent antibody staining showed the presence of RV specific antigens in the cytoplasm of HEMP cells (Fig. 1). These findings show that the HEMP cells were persistently infected with RV, and so they were designated as HEMP-RV cells. HEMP-RV cells consistently produce infectious virus particles at a titer of $10^{3}-10^{4} \mathrm{pfu} / \mathrm{ml}$. HEMP-RV cells

Figure 1. Indirect immunofluorescent antibody staining of HEMP cells persistently infected with RV. HEMP-RV cells were stained with preimmune rabbit $\operatorname{IgG}(A)$ or anti-RV rabbit antiserum $(B)$ as described in Methods. Note that fluorescence is absent in $A$ and present in cytoplasm in $B$. 



Figure 2. Phase-contrast microscopy of HEMP $(A)$ and HEMP-RV cells $(B)$. Cells were plated and cultured as described in Methods for $14 \mathrm{~d}$. HEMP-RV cells show an elongated and enlarged shape and regular cell arrangement when compared with HEMP cells. Photographs were taken at a magnification $\times 100$. 
demonstrated an elongated and enlarged shape when compared with HEMP cells (Fig. 2), which differs from the previous report (21).

Effect of EGF on HEMP and HEMP-RV cell growth. In a preliminary experiment, we have found that stimulation of HEMP cell growth by EGF is maximal at a concentration of 10 $\mathrm{ng} / \mathrm{ml}$ (data not shown). As shown in Fig. $3 A$, the growth rate of HEMP-RV cells was almost identical to that of HEMP cells, but cell density was slightly reduced. EGF stimulated cell division of HEMP and HEMP-RV cells by 2.2- and 1.5-fold, respectively. Similarly, EGF increased DNA synthesis of HEMP and HEMPRV cells by 5.7 - and 3.5-fold, respectively (Table I).

Effect of EGF on ALP activity in HEMP and HEMP-RV cells. ALP activity in HEMP cells increased markedly at $10 \mathrm{~d}$ in culture when their growth became stationary and, at $30 \mathrm{~d}$, reached 30 times of that in the cells at plating (Fig. $3 \mathrm{~B}$ ). The von Kossa stain of these cultures demonstrated the presence of spotlike mineral deposition (Fig. $4 A$ ). ALP activity in HEMP cells markedly increased in response to EGF (Table II). On the other hand, ALP activity in HEMP-RV cells remained low during the entire culture period (Fig. $3 \mathrm{~B}$ ). In parallel with this, HEMP-RV cultures stained negatively with the von Kossa stain for mineral deposition (Fig. 4 B). Furthermore, the enzyme activity showed no change after incubation with EGF (Table II).

Effect of EGF on collagen synthesis by HEMP and HEMP $R V$ cells. HEMP cells synthesized significant amounts of collagen and EGF inhibited it (Table II). Collagen synthesis by HEMPRV cells was one-third of that by HEMP cells and was unchanged in the presence of EGF (Table II). There was no difference in noncollagenous protein synthesis between HEMP and HEMPRV cells. EGF had no effect on noncollagenous protein synthesis (data not shown). At all concentrations of EGF examined (0.5$40 \mathrm{ng} / \mathrm{ml}$ ), we have found impaired or loss of responsiveness to EGF as assessed by cell growth, ALP activity, and collagen synthesis in HEMP-RV cells (data not shown).

${ }^{125}$ I-EGF binding and internalization in HEMP and HEMP$R V$ cells. As reported previously (6), ${ }^{125}$ I-EGF specifically bound
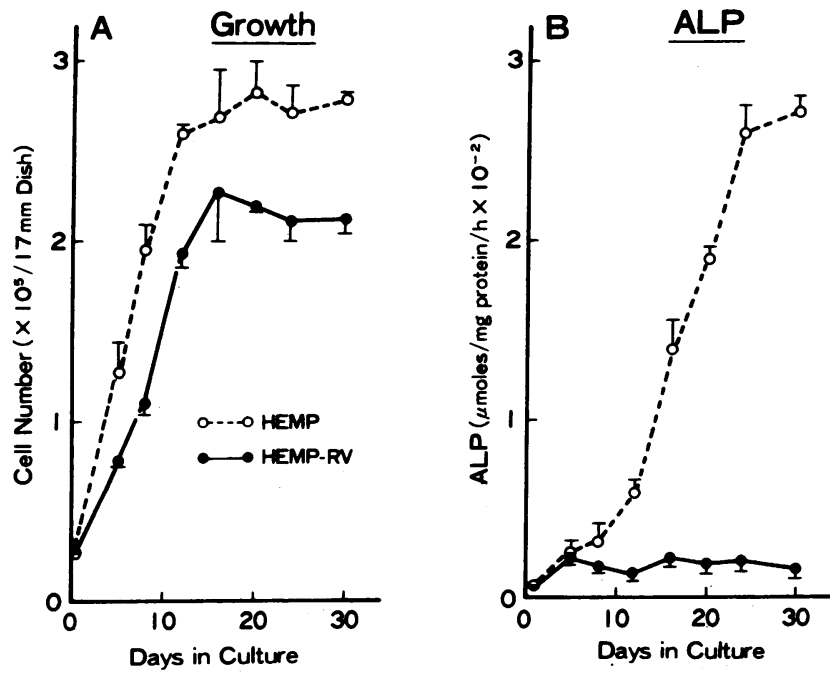

Figure 3. Relationship between growth $(A)$ and ALP activity $(B)$ in HEMP and HEMP-RV cells. HEMP and HEMP-RV cells $\left(2 \times 10^{4} /\right.$ $17 \mathrm{~mm}$ ) were plated and cultured in DME supplemented with 5\% FBS for the periods indicated. The culture medium was changed every $2 \mathrm{~d}$. Each point represents mean \pm SEM for four dishes.
Table I. Effect of EGF on Growth of HEMP and HEMP-RV Cells

\begin{tabular}{llllll}
\hline & \multicolumn{2}{l}{$\begin{array}{l}\text { Cell number* } \\
\left(10^{4} / 17 \text {-mm dish }\right)\end{array}$} & & \multicolumn{2}{l}{$\begin{array}{l}\text { DNA synthesis } \\
(\mathrm{dpm} / \mathrm{mg} \text { protein }\end{array}$} \\
\cline { 2 - 3 } Treatment & HEMP & HEMP-RV & & HEMP & HEMP-RV \\
\hline None & $3.9 \pm 0.3$ & $3.0 \pm 0.2^{\prime \prime}$ & & $52 ; 7$ & $39 \pm 4^{\prime \prime}$ \\
EGF & $8.5 \pm 0.5 \S$ & $4.4 \pm 0.2 \S^{\prime \prime}$ & & $294 \pm 30 \S$ & $138 \pm 14 \S^{\prime \prime}$
\end{tabular}

Values are mean \pm SEM for six determinations.

* HEMP or HEMP-RV cells were plated at a density of $2 \times 10^{4} / 17$ mm dish in DME supplemented with 5\% FBS. On the next day, the medium was replaced to serum-free DME supplemented with or without EGF $(10 \mathrm{ng} / \mathrm{ml})$ and the cells were grown for $4 \mathrm{~d}$. The cell number in each dish was counted as described in the text.

$\ddagger$ HEMP or HEMP-RV cells were plated at a density of $2 \times 10^{4} / 17$ $\mathrm{mm}$ dish and cultured in DME supplemented with 5\% FBS until they became subconfluent (5-7 d). The cells were then incubated in serumfree DME in the presence or absence of EGF $(10 \mathrm{ng} / \mathrm{ml})$ for $48 \mathrm{~h}$.

DNA synthesis was determined as described in the text.

$\S$ Significantly different from untreated group $(P<0.01)$.

"Significantly smaller than uninfected HEMP cells $(P<0.05)$.

to HEMP cells (Fig. $5 \mathrm{~A}$ ). Scatchard analysis of the binding data revealed that the affinity and capacity of the binding of ${ }^{125} \mathrm{I}-\mathrm{EGF}$ to HEMP cells is $1.1 \times 10^{-10} \mathrm{M}$ and $100 \mathrm{fmol} / \mathrm{mg}$ protein, respectively (Fig. $5 \mathrm{~B}$ ). In HEMP-RV cells, the affinity of the binding was decreased to $1.9 \times 10^{-10} \mathrm{M}$, but the capacity was increased twofold of that of HEMP cells (Fig. $5 \mathrm{~B}$ ). Internalization of ${ }^{125} \mathrm{I}$-EGF as measured by the amount of radioactivity resistant to acid extraction was significantly lower in HEMP-RV cells than that in HEMP cells (Fig. 6 B).

\section{Dịcussion}

It is generally recognized that in vitro establishment of persistent $\mathbf{R V}$ infection in primary cell cultures of human embryonic origin is difficult. Although there are several reports that describe establishment of diploid cells in RV carrier states, these cells were isolated from cogenitally infected human embryos and infants and showed comparably slow growth and limited life span (2225), and were therefore unsuitable for extensive study of the pathogenesis of the rubella syndrome. Since epidemiological and serovirological studies suggest that the congenital rubella syndrome is due to chronic or persistent infection of human embryos with $R V$, establishment of a suitable RV-infected embryonic cell line of human origin with functional markers of differentiation and growth is essential to elucidate the precise mechanism of viral pathogenesis. As mentioned previously, HEMP cells were isolated from a human embryo and are diploid and in primary culture because of their limited life span. However, these cells grow well in culture and, more importantly, possess biochemical markers associated with not only cell growth but differentiation including high ALP activity, collagen synthesis, and responsiveness to EGF. We have successfully established HEMP cells persistently infected with RV (HEMP-RV) that grow stably with consistent production of $R V$ particles and have subcultured $>20$ cell passages successively without fail. Thus, we feel that HEMPRV provide a useful model system for the study of the mechanisms involved in the rubella syndrome.

Persistent infection of HEMP cells with RV resulted in 

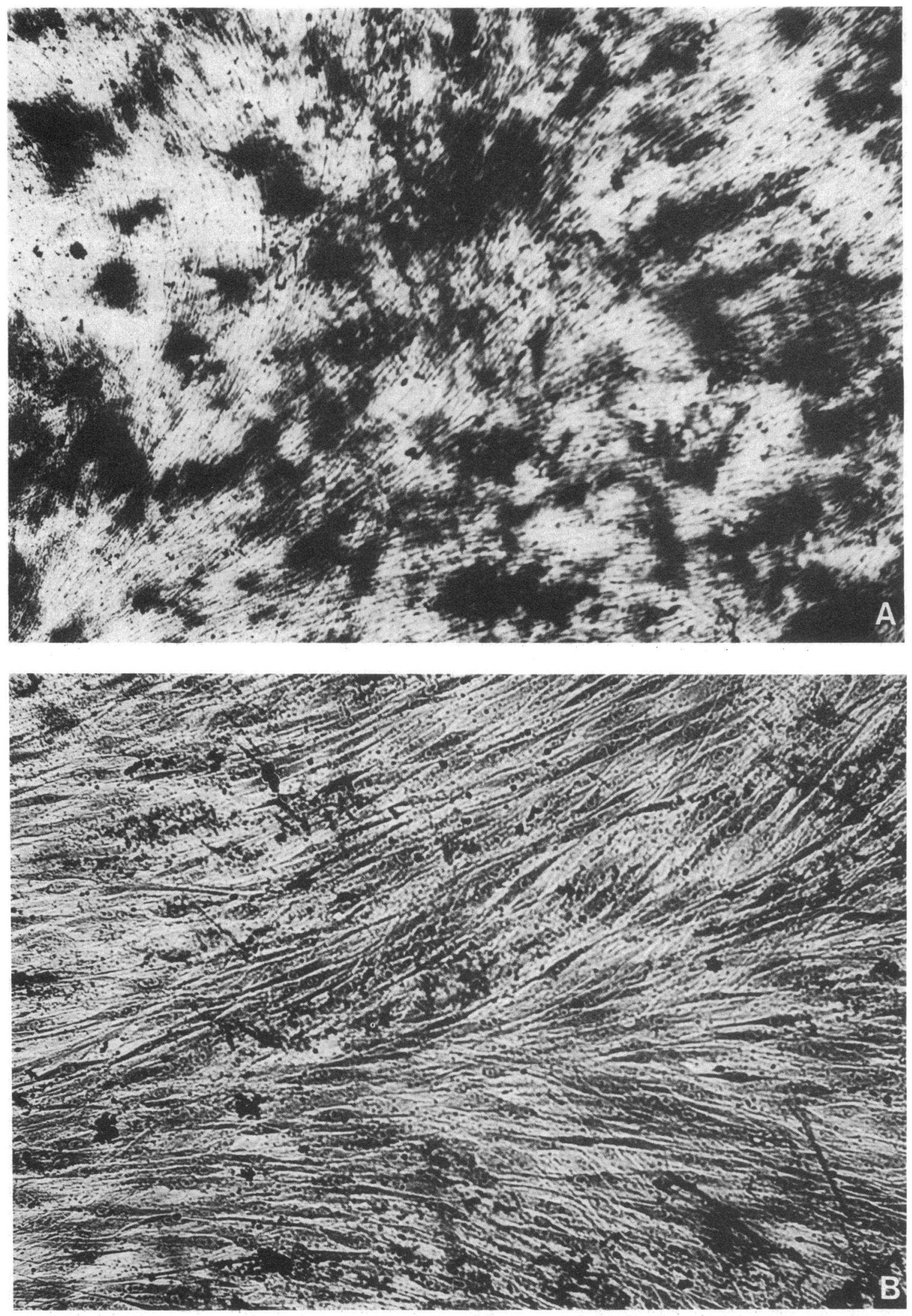

Figure 4. Von Kossa stain of HEMP $(A)$ and HEMP-RV $(B)$ cells $\left(2 \times 10^{5} / 17 \mathrm{~mm}\right)$ cultured for $2 \mathrm{wk}$ in the presence of $5 \mathrm{mM}$ beta-glycerophosphate. Note that dark black stain which represents mineral deposition is present in $A$ and absent in $B$. Photographs were taken at a magnification $\times \mathbf{4 0}$. 
Table II. Effect of EGF on ALP Activity and

Collagen Synthesis in HEMP and HEMP-RV Cells

\begin{tabular}{|c|c|c|c|c|}
\hline \multirow[b]{2}{*}{ Treatment } & \multicolumn{2}{|c|}{$\begin{array}{l}\text { ALP activity }{ }^{*} \\
(\mu \mathrm{mol} / \mathrm{mg} \text { protein } / \mathrm{h})\end{array}$} & \multicolumn{2}{|c|}{$\begin{array}{l}\text { Collagen synthesis } \ddagger \\
\text { (\% collagen synthesized) }\end{array}$} \\
\hline & HEMP & HEMP-RV & HEMP & HEMP-RI \\
\hline None & $48 \pm 5$ & $18 \pm 1^{11}$ & $12.3 \pm 1.0$ & $4.3 \pm 0.3^{\prime \prime}$ \\
\hline EGF & $102 \pm 10 \S$ & $17 \pm 1^{11}$ & $6.3 \pm 0.4 \S$ & $4.6 \pm 0.4^{\prime \prime}$ \\
\hline
\end{tabular}

Values are mean \pm SEM for six determinations.

* HEMP or HEMP-RV cells were plated at a density of $2 \times 10^{5} / 17-$ $\mathrm{mm}$ dish and cultured in DME supplemented with 5\% FBS for $10 \mathrm{~d}$. The cells were then incubated in serum-free DME in the presence or absence of EGF $(10 \mathrm{ng} / \mathrm{ml})$ for $48 \mathrm{~h}$ and ALP activity in the cells was measured. ALP activity in the incubation medium was $<1 / 10$ of that in the cells and was not changed by EGF.

$\ddagger$ HEMP or HEMP-RV cells were plated at a density of $2 \times 10^{5} / 17$ $\mathrm{mm}$ dish and cultured in DME supplemented with 5\% FBS for $10 \mathrm{~d}$. The cells were then incubated and collagen synthesis was assayed as described in the text.

$\S$ Significantly different from untreated group $(P<0.01)$.

"Significantly smaller than uninfected HEMP cells $(P<0.01)$.

marked decreases in ALP activity (Fig. $3 B$ ) and collagen synthesis (Table II) and loss of responsiveness to EGF with respect to parameters associated with HEMP cell differentiation (Table II). Furthermore, HEMP cell growth was also affected (Fig. 3 $A$ ), which is compatible with the previous reports $(21,25)$, and stimulation of growth by EGF was impaired in HEMP-RV cells (Table I). It is likely that HEMP cells lose the capacity for differentiation and show reduced growth under the influence of persistent RV infection. Similar results were described by Oldstone et al. (26), who employed a transformed cell line with functional markers in their experiments. They found that persistent infection of mouse neuroblastoma cells with lymphocytic choriomeningitis virus caused decreased synthesis of choline acetyl transferase and acetylcholine esterase. In addition to these in vitro results, they have shown that in animals persistently infected with the same virus, production and degradation of
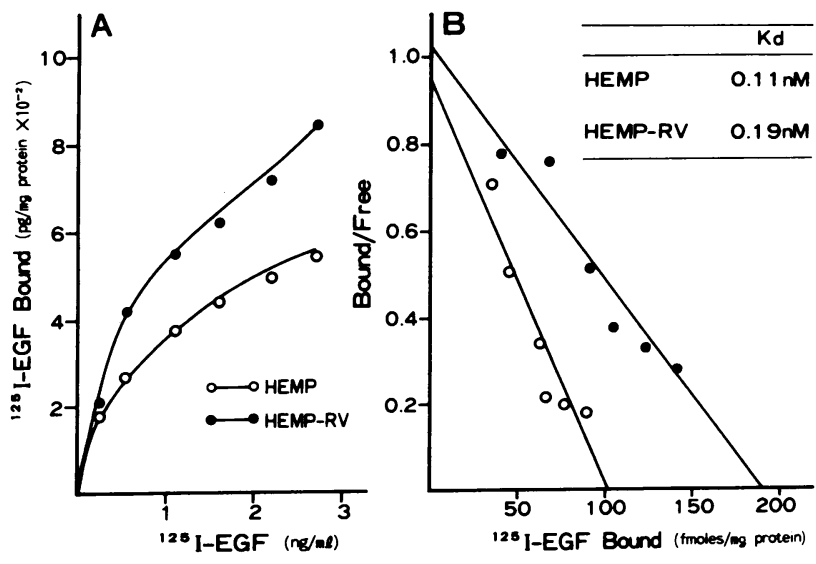

Figure 5. ${ }^{125} \mathrm{I}-\mathrm{EGF}$ binding to HEMP and HEMP-RV cells $(A)$. Scatchard analysis of Fig. $5 A(B)$. HEMP and HEMP-RV cells $\left(2 \times 10^{5} /\right.$ $17 \mathrm{~mm}$ ) were cultured for $10 \mathrm{~d}$ and the binding of ${ }^{125}$ I-EGF to the cells was determined as described in Methods. Each point represents mean \pm SEM for four dishes.

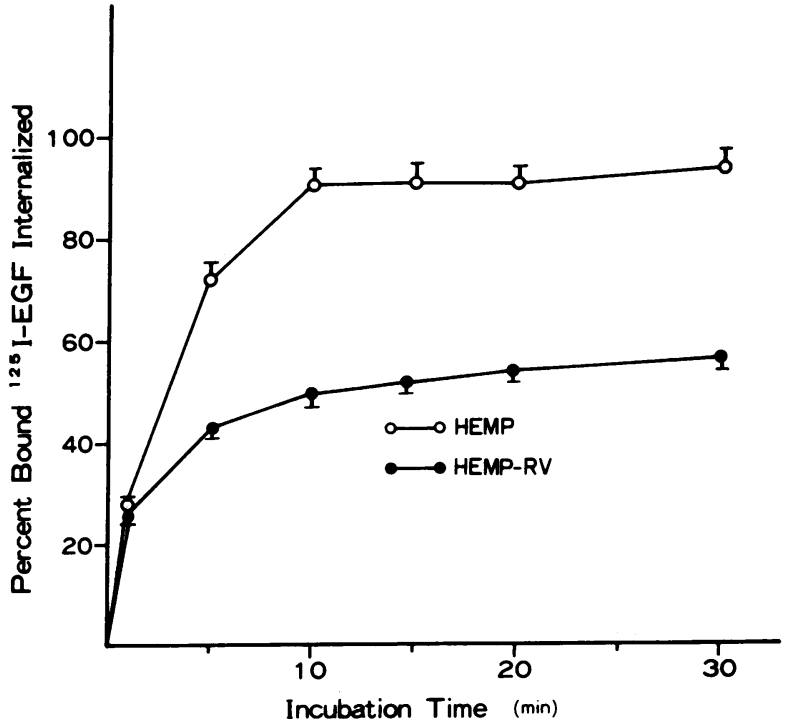

Figure 6. Internalization of bound ${ }^{125}$ I-EGF in HEMP and HEMP-RV cells. Each point represents mean \pm SEM for four dishes.

acetylcholine were significantly altered (26). Recently, the same virus has been shown to perturb endocrine function of pituitary gland cells in experimental animals $(27,28)$. These in vitro and in vivo findings led these workers to suggest that alterations of cell functions by persistent virus infection might be implicated in the mechanisms of virus-induced diseases. Furthermore, Van Alstyne et al. have found that RV replication was activated when rat glial cells differentiate into mature glia by treatment with dibutyryl cyclic AMP and suggested that their findings might be significant for better understanding of chronic and progressive neurologic disortlers related to persistent $\mathrm{RV}$ infection in the central nervous system (29). Very recently, the roles of reovirus in the production of human disease has been also described (30). Although we realize the hazards of correlating in vitro results directly with in vivo events, nonetheless our results together with previous reports (26-30) suggest that $R V$-induced diseases might occur partly through direct RV influence on differentiated function and growth of cells as well as through defects of the immune system caused by RV infection (31).

Tyler and Koch have demonstrated that palatal mesenchyme of mouse embryo, when cultured under isolated conditions, forms intramembranous bone, suggesting that palatal mesenchymal cells are related to osteoblast precursors (32). In the present experiments, we have found that HEMP cells showed increasing ALP content after confluency (Fig. 3.B) associated with mineral deposition (Fig. $4 A$ ) and synthesized collagen. Immunofluorescent staining of confluent HEMP cells showed that collagen synthesized by the cells is mostly type I collagen. ${ }^{2}$ ALP activity and type I collagen synthesis are well-accepted biochemical parameters of osteoblastic activity (33) and bone formation (34), respectively. In addition, ALP activity, collagen synthesis, and cAMP content of HEMP cells were modulated by the osteotropic hormones parathyroid hormone, 1,25-dihydroxyvitamin $D_{3}$, prostaglandin $E_{2}$, and calcitonin $(9)^{2}$, indicating that HEMP cells are responsive to these hormones. Thus, HEMP cells are behaving in some ways like cells with the osteoblast phenotype. We also found that EGF increased ALP activity in HEMP cells (Table II), which is opposite to the data of Kume- 
gawa et al. (35) and, similarly to a previous report $(36 ; 37)$, inhibited collagen synthesis (Table II). EGF has been shown to influence bone cell metabolism (34). It is, therefore, likely that HEMP cells have some osteoblastic properties. Our findings of no increase in ALP activity (Fig. $3 B$ ), no mineral deposition (Fig. $4 \mathrm{~B}$ ), marked decrease in collagen synthesis, and loss of responsiveness to EGF in HEMP-RV cells are of particular interest in view of the osseous abnormalities seen in congenital rubella syndrome. $\mathrm{RV}$-induced congenital osteopathy consisting of metaphyseal radiolucent lesion in long bones and poor mineralization of the calvarium $(5,38-40)$ has been emphasized in addition to the clinical manifestations described above. Heggie reported that RV inhibited growth of human embryonic and fetal rat bones in organ culture (4i), raising a possibility that RV directly affects skeletal growth. Concentration of RV in cartilagenous tissues that presumably results in delayed ossification and retarded bone growth has been also reported (42). Thus, our findings together with these reports indicate that $R V$-induced osteopathy is due to not only indirect nutritional and/or metabolic disturbances caused by RV infection in other organs but the direct effect of RV on bone and cartilage cells. We, therefore, would like to propose that alterations of growth and differentiation of HEMP cells by persistent RV infection might be implicated in the mechanism of the bone lesions seen in congenital rubella syndrome.

Since the biological actions of EGF are mediated through specific and high affinity membrane-bound receptors and we already demonstrated that HEMP cells possess specific receptors for EGF with high affinity.(6), it is likely that impaired responsiveness of HEMP-RV cells to EGF is due to alteration of EGF receptor expression by $R V$ infection. To our surprise, however, the number of EGF receptors in HEMP-RV cells was greater than that in uninfected counterparts (Fig. 5). Thus, there is an apparent dissociation between EGF binding and EGF action in HEMP-RV cells. Recently, a similar observation has been made in streptozotocin-induced diabetic rats (43). In these rats, the effects of insulin on the liver are diminished despite increased insulin binding to its receptors (43). We have examined internalization of bound EGF in HEMP and HEMP-RV cells and found that internalization of bound EGF in HEMP-RV cells is profoundly reduced compared with that in HEMP cells (Fig. 6). We speculate therefore that in HEMP-RV cells a process occurring on the plasma membrane subsequent to binding but before internalization might be altered by RV infection. Since it is known that as a first step of viral infection, virus binds to cell-surface receptors (30) and RV is known to be an enveloped virus that buds from the plasma membrane in the replication process (44), it is likely that persistent RV infection modifies plasma membrane structure and function to interfere with binding of EGF and internalization of EGF-receptor complex. Thus, we suggest that decreased responsiveness of HEMP-RV cells to EGF is, at least in part, due to reduced internalization of bound EGF.

It is unknown whether the results obtained in HEMP-RV cells are specific for $R V$ infection. However, as mentioned earlier, establishment of HEMP cells persistently infected with a virus is difficult, and it is not unexpected that acute viral infection results in alteration of HEMP cell growth and differentiation. In addition, persistent infection of HEMP cells with an oncogenic virus is unlikely to be related to the purpose of our present study, since congenital RV disease is not a neoplastic disease. Furthermore, HEMP-RV cells failed to form colonies in semi-solid agar or to form tumors when transplanted in athymic nude mice (data not shown), indicating that HEMP-RV cells are not transformed. Thus, it should be noted that our data were obtained in nontransformed HEMP cells chronically infected with RV with no cytopathic effects, providing an experimental model more closely reflecting the in vivo situation of $R V$ infection. Although we did not examine the effect of other viruses on HEMP cell growth and differentiation, we believe our findings are of potential importance to an understanding of the mechanism of virus-induced diseases:

\section{Acknowledgments}

We are grateful to Dr. Gregory R. Mundy for his helpful discussion and Mutsuko Tamai and Nancy Garrett for their secretarial assistance.

\section{References}

1. Gregg, N. M. 1941. Congenital cataract following German measles in mother. Trans. Ophthalmol. Soc. Australia. 3:35-46.

2. Rudolph, A. J., M. D. Yow, C. A. Phillips, M. M. Desmond, R. J. Blattner, and J. L. Melnick. 1965. Transplacental rubella infection in newly born infants. J. Am. Med. Assoc. 191:843-845.

3. Korones, S. B., L. E. Ainger, G. R. G. Monif, J. Roane, J. L. Sever, and F. Fuster. 1965. Congenital rubella syndrome: new clinical aspects with recovery of virus from affected infants. J. Pediatr. 67:166181.

4. Cotlier, E., J. Fox, G. Bohigian, C. Beaty, and A. D. Pree. 1968. Pathogenic effects of rubella virus on embryos and newborn rats. Nature (Lond.). 217:38-40.

5. Singleton, E. B., A. J. Rudolph, H. S. Rosenberg, and D. B. Singer. 1966. The roentgenographic manifestations of the rubella syndrome in newborn infants. Am. J. Roentgenol. Radium Ther. Nucl. Med. 97:8291.

6. Yoneda, T., and R. M. Pratt. 1981. Mesenchymal cells from the human embryonic palate are highly responsive to epidermal growth factor. Science (Wash. DC). 213:563-565.

7. Yoneda, T., and R. M. Pratt. 1981. Interaction between glucocorticoids and epidermal growth factor in vitro in the growth of palatal mesenchymal cells from the human embryo. Differentiation. 19:194198.

8. Yoneda, T., N. Nishikawa, and M. Sakuda. 1984. Responsiveness of mesenchymal cells from human embryonic palate (HEMP cells) to calcium-regulating hormones. In Endocrine Control of Bone and Calcium Metabolism. D. V. Cohn, T. Fujita; J. T. Potts, and R. V. Talmage, editors. Excerpta Medica, Amsterdam-New York, Oxford. 246-247.

9. Yoneda, T., and R. M. Pratt. 1981. Glucocorticoid receptors in palatal mesenchymal cells from the human embryo: relevance to human cleft palate formation. J. Cranio. Genet. Dev. Biol. 1:411-423.

10. Sato, M., M. Urade, N. Maeda, T. Miyazaki, Y. Watanabe, T. Shiba, and N. Yamamoto. 1978. Isolation and characterization of a new rubella variant with DNA polymerase activity. Arch. Virol. 56:89-103.

11. Dulbecco, M., and M. Vogt. 1954. Plaque formation and isolation of pure lines with poliomyelotis virus. J. Exp. Med. 99:167-187.

12. Sato, M., N. Maeda, M. Urade, M. Kuribayashi, K. Shirasuna, H. Yoshida, and T. Miyazaki. 1978. Persistent infection of primary human cell cultures with rubella variant carrying DNA polymerase activity. Arch. Virol. 56:181-187.

13. Majeska, R. J., and G. A. Rodan. 1982. Alkaline phosphatase inhibition by parathyroid hormone and isoproterenol in a clonal rat osteosarcoma cell line. Possible mediation by cyclic AMP. Calcif. Tissue Int. 34:59-66.

14. Lowry, O. H. 1955. Micromethods for the assay of enzyme. II. Specific procedures. Alkaline phosphatase. Methods Enzymol. 4:371372.

15. Binderman, I., R. M. Greene, and J. P. Pennypacker. 1979. Calcification of differentiation skeletal mesenchyme in vitro. Science (Wash. DC). 206:222-225.

16. Scott, D. M., G. N. Kent, and D. V. Cohn. 1980. Collagen syn- 
thesis in cultured osteoblast-like cells. Arch. Biochem. Biophys. 201:384391.

17. Peterkofsky, G., and R. Diegelman. 1971. Use of a mixture of proteinase-free collagenases for the specific assay of collagen in the presence of other proteins. Biochemistry. 10:988-994.

18. Raisz, L. G., D. M. Maina, S. C. Gworek, J. W. Dietrich, and E. M. Canalis. 1978. Hormonal control of bone collagen synthesis in vitro: inhibitory effect of 1-hydroxylated vitamin D metabolites. Endocrinology. 102:731-735.

19. Haigler, H. T., F. R. Maxfield, M. C. Willingham, and I. Pastan. 1980. Dansylcadaverine inhibits internalization of ${ }^{125}$ I epidermal growth factor in Balb 3T3 cells. J. Biol. Chem. 253:3970-3977.

20. Lowry, O. H., N. J. Rosebrough, A. L. Farr, and R. J. Randall. 1951. Protein measurement with folin phenol reagent. J. Biol. Chem. 193:265-275.

21. Plotkin, S. A., and A. Vaheri. 1967. Human fibroblasts infected with rubella virus produce a growth inhibitor. Science (Wash. DC). 156: 659-661.

22. Kay, H. E. M., M. E. Peppercorn, J. S. Porterfield, K. McCarthy, and C. H. Taylor-Robinson. 1964. Congenital rubella infection of a human embryo. Br. Med. J. 2:166-167.

23. Goffe, A. 1965. A diploid human cell strain with chronic inapparent rubella infection. Arch. Gesamte Virusforsch. 16:149.

24. Plotkin, S. A., A. Boue, and J. G. Boue. 1965. The in vitro growth of rubella virus in human embryo cells. Am. J. Epidemiol. 81:71-85.

25. Rawls, W. E., and J. L. Melnick. 1966. Rubella virus carrier cultures derived from congenitally infected infants. J. Exp. Med. 123: 795-816.

26. Oldstone, M. B. A., J. Holmstoen, and R. M. Welsh, Jr. 1977. Alterations of acetylcholine enzymes in neuroblastoma cells persistently infected with lymphocytic choriomeningitis virus. J. Cell. Physiol. 91: 459-472.

27. Oldstone, M. B. A., Y. N. Shinha, P. Blout, A. Tishon, M. Rodriguez, R. von Wedel, and P. W. Lampert. 1982. Virus-induced alterations in homeostasis: alterations in differentiated functions of infected cells in vivo. Science (Wash. DC). 218:1125-1127.

28. Oldstone, M. B. A., M. Rodriguez, W. H. Daughoday, and P. W. Lampert. 1984. Viral perturbation of endocrine function: disordered cell function leads to disturbed homeostasis and disease. Nature (Lond.). 307:278-281.

29. Alstyne, D. V., and D. W. Paty. 1983. The effect of dibutyryl cyclic AMP on restricted replication of rubella virus in rat glial cells in culture. Virology. 124:172-180.

30. Sharpe, A. H., and B. N. Fields. 1985. Pathogenesis of viral infections. Basic concepts derived from the reovirus model. N. Engl. J. Med. 312:486-497.

31. Rawls, W. E. 1974. Viral persistence in congenital rubella. Prog. Med. Virol. 18:273-288.

32. Tyler, M. S., and W. E. Koch. 1977. In vitro development of palatal tissues from embryonic mice. II. Tissue isolation and recombination studies. J. Embryol. Exp. Morphol. 38:19-36.

33. Robinson, R. A., S. B. Doty, and R. R. Cooper. 1973. Electron microscopy of mammalian bone. In Biological Mineralization. I. Zipkin, editor. Academic Press, Inc., New York. 257-296.

34. Raisz, L. G., and B. E. Kream. 1983. Regulation of bone formation. N. Engl. J. Med. 309:29-35, 83-89.

35. Kumegawa, M., M. Hiramatsu, K. Hatakeyama, T. Yajima, H. Kadama, T. Osaki, and K. Kurisu. 1983. Effects of epidermal growth factor on osteoblastic cells in vitro. Calcif. Tissue Int. 35:542-548.

36. Canalis, E. M., and L. G. Raisz. 1979. Effect of epidermal growth factor on bone formation in vitro. Endocrinology. 104:862-886.

37. Hata, R., H. Hori, Y. Hagai, S. Tanaka, M. Kondo, M. Hiramatsu, N. Utsumi, and M. Kumegawa. 1984. Selective inhibition of type I collagen synthesis in osteoblastic cells by epidermal growth factor. Endocrinology. 115:867-876.

38. Rudolph, A. J., E. B. Singleton, H. S. Rosenberg, D. B. Singer, and C. A. Phillips. 1965. Osseous manifestations of the congenital rubella syndrome. Am. J. Dis. Child. 110:428-433.

39. Sekeles, E., and A. Ornoy. 1975. Osseous manifestations of gestational rubella in young human fetuses. Am. J. Obstet. Gynecol. 122: 307-312.

40. Reed, G. B. 1969. Rubella bone lesions. J. Pediatr. 74:208-213.

41. Heggie, A. D. 1976. Growth inhibition of human embryonic and fetal rat bones in organ culture by rubella virus. Teratology. 15:47-56.

42. London, W. T., D. A. Fuccillo, B. Anderson, and J. L. Sever. 1970. Concentration of rubella virus antigen in chondrocytes of congenitally infected rabbits. Nature (Lond.). 226:172-173.

43. Kadowaki, T., M. Kasuga, Y. Akanuma, O. Ezaki, and F. Takaku. 1984. Decreased autophosphorylation of the insulin receptor-kinase in streptozotacin-diabetic rats. J. Biol. Chem. 259:14208-14216.

44. Becker, Y. 1976. Antiviral drugs: mode of action and chemotherapy of viral infections of man. Monogr. Virol. 11:1-130. 